\title{
The Concept of "Communication" in Contemporary Research
}

\author{
Natalia P. Koptseva*a, \\ Ma Liia ${ }^{a}$ and Vladimir I. Kirko ${ }^{b}$ \\ ${ }^{a}$ Siberian Federal University \\ 79 Svobodny, Krasnoyarsk, 660041, Russia \\ ${ }^{b}$ Krasnoyarsk State Pedagogical University \\ named after V.P. Astafiev \\ 89 Ada Lebedeva Str., Krasnoyarsk, 660060, Russia
}

Received 12.04.2015, received in revised form 16.06.2015, accepted 18.07.2015

The article is a review of the research of the communication phenomenon, including the history of formation of the theory of communication, communication models. The article considers communication models of various authors. The chronological analysis of the theories and models of communication is about 100 years, from the 20 s of the 20 th century to the present. The article analyzes the modern definition of communication of Russian and international authors, reveals the structure of these definitions and their basic content. Then we consider the theory of communication, ranging from Harry Nyquist to Harold Lasswell. The final section of the article chronologically examines the most important modern communication models of such authors as Shannon and Weaver, Berlo, Schramm, Barnlund, Innis, Craig. Finally, we make conclusions on the current trends in the research of communication practices.

Keywords: communication, models of communication, information, social communication, encoding and decoding.

The research was carried out within the grant of RFH 15-16-24007 devoted to the topic: "Complex Research of Indigenous Small Peoples of the Arctic Zone of the Eastern Siberia in the Field of Fundamental Medical Care, Distance Education, Socio-cultural and Economic Activities".

DOI: 10.17516/1997-1370-2015-8-8-1560-1568.

Research area: culture studies, philosophy.

\section{Introduction:}

\section{definitions of communication}

The phenomena of communication and informationreveal thespecificity ofmodernsociety (Bakhova et al., 2012, Reznikova and Koptseva, 2013). Communication processes become more intensified, the amount of communicating people is constantly increasing (Ilbeikina, 2013, Kolesnik, 2014, Semenova, 2012). Communicative environments are ambiguous and appear in alternative forms (Nikitina and Pimenova, 2014, Razumovskaya, 2012, Semenova, 2012).

C) Siberian Federal University. All rights reserved

* Corresponding author E-mail address: decanka@mail.ru 
Currently, each communication message can be changed and substituted by quite a different message. On the contrary, in traditional societies, each communicative action was unique and predetermined social stratification. At the same time, the range of scientific disciplines studying both the phenomenon of communication and the technology of communicative actions, the social value of which has been constantly increasing, has been widening (Ma Liia, 2015). The information transmitted during the communicative act has proved to be one of the most important productive forces of the modern society, which was recorded, in particular, in the concepts of the information society (Daniel Bell (1999) and Alvin Toffler (2010)). Communication is both a sign and a symbol of the modern human society.

This concept of communication in the modern social cognition has been conceived for the last hundred years in the context of linguistic approaches. The classical versions of the modern social philosophy determine communication as 1) a means of connecting both material and spiritual objects; 2) a transfer of information from one person to another; 3 ) an exchange of information in the social space with the aim to change it (Davydov et al., 1990, p. 131). M.S. Kagan divides the concepts of intercourse and communication, as they are different forms of interaction between people, communities, cultures. $\mathrm{He}$ understands communication only as messaging, a data exchange, while intercourse is not only informative, but also material, spiritual, creative and practical interaction (Kagan, 1988, p.116). The researcher considers communication as a one-way process, whereas the concept of intercourse implies interaction. This position is irrelevant, currently the subject of communication is understood both as the sender and the recipient of the message (not consequently, but simultaneously).
In Russian studies, communication is most often defined as a form of human interaction, which is characterized by the exchange of information. The weak point in this thesis is vague and ambiguous understanding of information. In its everyday meaning information is understood as a certain content, but until recently, understanding of this content in social cognition has not been analyzed, and the term "information" was used rather intuitively, than at the scientific and logical level.

Information as a concept was first explored in mathematical and technical sciences, where it was defined as a measure of quantitative measurement of data distributed via technical communication channels. The content of the data is of no importance. In this case, information is an element of a cybernetic model, its amount is characterized by uncertainty. Cybernetic information models had been created by Shannon and W. Weaver (Shannon \& Weaver, 1949), (Moles, 2008), (Luhmann, 2000). In A.V. Sokolov's theory, information is understood as abstraction, mental construct that indicates the informational methodological principle of science (Sokolov, 2002, p. 308).

In the theory of A. Toffler and D. Bell, the information society is seen as a new social paradigm, a specific form of civilization unit to substitute the agrarian and industrial societies. The ways of information existence and its processing are determined by the ways of modern production. Thus, information and communication are discussed in the technology context as a synthesis of science and information including scientific and technical information flows, the actual information technology, subjects-carriers of socially important knowledge.

C. Cooley in "Social Organization" defines communication as "the mechanism through which human relations exist and develop-all the symbols of the mind, together with the means of 
conveying them through space and preserving them in time". There is no sharp line between the means of communication and the rest of the external world. However, along with the birth of the external world the system of standard symbols to be used solely for the transmission of thoughts appears, here the traditional communication development begins" (Cooley, 1994, p. 379).

The descriptive definition of communication is typical for G.G. Pocheptsov, who defines communication as "transcoding processes of the verbal into the non-verbal and the non-verbal into the verbal spheres. Historically, it was exactly what communication was: forcing another person to perform a particular action. The transition from speaking of the One to the actions of the Other is essential for communication. For this sake the transfer of meanings is performed between two different autonomous systems, which are the two men" (Pocheptsov 2001, p.16). Harold Lasswell, a representative of the Chicago School of Sociology, a political scientist, outlines five characteristics of the communication process in his work of 1948 "The Structure and Function of Communication in Society": who is transmitting what and to whom using what channel and obtaining what result (Lasswell, 1994, p. 133).

All these definitions outline understanding of communication as a special kind of social interaction, where communicative actions are consciously oriented at the semantic perception.

\section{Theories of Communication}

The beginning of the theories of communication is associated with the intellectual history of the $20 \mathrm{~s}$ of the $20^{\text {th }}$ century, when the American engineer Harry Nyquist in his article of 1924 "Some Factors That Affect the Speed of the Telegraph" (Rogers, 1986) provided a theoretical section, which analyzed aspects related to the intelligence transmission rate by means of communication tools. Then, in 1928,
Ralph Hartley, in his article "The Transmission of Information" (Craig, 1999) defined information as a sequence of symbols that can be quantified technically.

The communication theory was first established by Claude Shannon in 1948 in his work "The Mathematical Theory of Communication" (Craig, 1999), where the author focuses on solving the problem of the best coding of information that the sender wants to transmit. Shannon introduces the concept of information entropy as a measure of uncertainty in the message. In the $40 \mathrm{~s}$ of the $20^{\text {th }}$ century, the American theory of communication was developing through the research of secret codes, the mathematical theory of cryptography. In the $50 \mathrm{~s}$ of the $20^{\text {th }}$ century, Claude Shannon, Warren Weaver and other researchers applied the theory of communication in psychology and sociology (Shannon \& Weaver, 1949). They created the concept of "a transmitted model", introduced a unit of measurement of information "bytes per second". Computer science appears as a scientific and technical discipline. The pattern of communication of Shannon and Weaver outlines three elements: sender - channel - recipient. These scientists also introduce the term "noise" as a lack of communication in the presence of all three elements of the communication model. Shannon and Weaver describe three levels of problems typical for this model: 1) the technical problem - how accurately the message can be transmitted; 2) the semantic problem - how the meaning is transmitted; 3) the problem of efficiency - how effectively the meaning of the message affects behaviour.

This model was criticized by Daniel Chandler, who drew attention to the fact that this model considers communicators as people completely isolated from each other, possible differences in the goals of communicating entities are not taken into consideration, as well as their differences in interpretation of received 
messages, and finally, the difference in the social status, a possible hierarchy of communicating entities is neglected (Craig, 1999).

Wilbur Schramm (1907-1987) focused his research on the experience of the sender and the recipient. He formulated the principle according to which communication is possible only when the sender and recipient share a common language (Schramm, 1954, Schramm, 1963) This idea was developed by Everett Rogers and communication studies soon transformed into a separate scientific discipline (Rogers, 1986).

In 1960, David Burleigh, a student of Shannon and Weaver, created SMCR Model of communication: Source - Message - Channel Receiver (Craig, 1999). This model is widely used in communication studies, complemented by other scientists.

Communication is usually described in terms of several parameters: message type, sender's quality, form of communication, channel (communication method), purpose, recipient's quality (receiving entity). Wilbur Schramm (1954) also pointed at the importance of analyzing the impact of the message itself on obtaining the objectives of the message (Schramm, 1954). Communication parties may share knowledge and experience, give advice and instructions, ask questions. These forms of communication differ substantially from each other. The message format depends on the communication skills of communicating entities. Form and content of communication together constitute the "message", the objective of which may be in the message itself, or this objective may be directed at another person, as well as a group of entities (corporations, for example). Schramm defines communication as the process of transmission of information that is subject to the rules of three groups: 1) syntactic (showing formal properties of signs and symbols); 2) pragmatic (showing relations between signs/ expressions and those who use them); 3) semantic (which show the relationship between the sign and the meaning, between the symbol and what the symbol indicates).

Thus, social communication requires a common set of signs and a common set of semiotic rules. It does not clarify the situation of autocommunication, intrapersonal communication through writing diaries or conversations of a person to themselves, which are described as secondary phenomena arising after the fact that a subject has got to know a common set of signs and semiotic rules.

In this regard, D. Barnlund in 1970 offered his own communication model, where sending and receiving of messages occur simultaneously (Barnlund, 1968). In a more complex model, the sender and the recipient of the message are interrelated. Here the focus is on the form of the message, the sender's personal filters and the recipient's personal filters. The information transmitted is considered separately from the message. The specific form of communication is named "the speech act", where personal information filters can vary considerably depending on regional traditions, culture, gender (Libakova \& Koptseva 2013, Luzan, 2014 Seredkina, 2014 Theory and practice ..., 2013). These factors can significantly change the objectives of the message. The speech act can be not carried out due to the information noise. The most important steps of this model are coding and decoding (Razumovskaya 2012). Obviously, coding and decoding of information in the message can differ significantly for the sender and the recipient.

In the $90 \mathrm{~s}$ of the $20^{\text {th }}$ century, the theory of co-regulation of communication was developed, where communication is considered not discretely, but as a continuous and dynamic creative process. Harold Innis assumed that using the media people will be able to communicate using the ways of communication they want, and that the preferential 
choice of these methods of mass communication is the form and measure of strength of social relations (Innis, 1951). The example of Ancient Egypt is given, where the media existed in the form of stone and papyrus. Papyrus made the dissemination of information possible in the form of written orders throughout the empire, from the center to the colonies, to remote military units. Thus, papyrus organized the social space of mass communications of Ancient Egypt. In turn, stone became the organizer of the social time. Stone works of architecture provided communication between generations, and the power of pharaohs was disseminating itself both in space and time.

Beginning from the $70 \mathrm{~s}$ of the $20^{\text {th }}$ century communication models have been considered in the context of social psychology. In 1998, the Association of American Psychologists published thetargetreport, whichprovesthatimages, graphics and sound dominate over verbal texts in modern communications (Ilbeikina 2013, Kolesnik, 2014 Luzan, 2014, Semenova, 2012). In terms of the psychological model of communication verbal texts, including books, should obligatorily have some of the necessary elements in order to reduce possible communication distortions, including: a) navigational tools that reveal the most effective ways of using the book; b) a list of keywords at the beginning of each chapter, these keywords should be highlighted inside the chapter; c) a detailed glossary of words and phrases; d) specific instructions related to the impact of processes of identification, resistance, rumors, gossip, etc.

In 1999, Robert Craig wrote an article "The Theory of Communication as a Field", where he noted the presence of many theories of communication that have little to do with each other (Craig, 1999). In this regard, he proposed to convert theories of communication in the practice of communication. All communication theories outlined by Robert Craig may to some extent be used for effective teaching of practices of communication, effective dialogue practices. R. Craig's article recorded a turn of the theoretical disciplines in the practical sphere typical for the $21^{\text {st }}$ century. At the present time, theories of communication exist in objectified form of specific communicative practices (Seredkina, 2014 Sertakova, 2010). Despite the general trend of the practical turn, modern models of communication are created in the theoretical space of linguistics and philosophy.

\section{Conclusion}

1. Communication is the subject of research of special communication theories, which consider some elements of the communication process, as well as the effects that arise from the interaction of these elements.

2. The most important trend in the modern communication theory is the study of the processes of coding and decoding the information in the message, and the coding and decoding processes differ significantly depending on the cultural characteristics of the communicating entities. The specifics of the coding and decoding of information in the communicative process predetermines the specific implementation of the objectives of the communicative process.

3. Since the late $90 \mathrm{~s}$ of the $20^{\text {th }}$ century theoretical modeling of communication gives way to the development of applied models of effective communication. Theoretical discoveries are transformed into practical skills of the effective dialogue. In connection with this, the importance of one or another particular theoretical model of communication decreases. The ability of this particular theory of communication to transform into the basis of the effective communication practice comes into the first place. 


\section{References}

1. Averkina L.A. Neverbal'naia kommunikatsiia vazhnyi aspekt mezhkul'turnoi kommunikatsii [Non-verbal Communication: an Important Aspect of Intercultural Communication]// Vestnik Moskovskogo gosudarstvennogo lingvisticheskogo universiteta [Bulletin of Moscow State Linguistic University]. 2008. № 554. P. 123-133.

2. Bachurina N.S. Kontseptualizatsiia integrirovannykh kommunikatsii: poiski svoeobraziia poniatiia po sravneniiu s integrirovannymi marketingovymi kommunikatsiiami [Conceptualization of Integrated Communications: Search for the Concept Identity Compared to Integrated Marketing Communications]// Ekonomicheskie i gumanitarnye nauki [Economic Sciences and the Humanities]. 2014. № 9 (272). P. 84-95.

3. Barnlund, D. C. Interpersonal Communication: Survey and Studies. Boston: Houghton Mifflin, 1968.

4. Bakhova N.A., Zamaraeva Iu.S., Kirko V.I., Koptseva N.P. Problema sotsiokul'turnykh issledovanii v sovremennoi gumanitarnoi nauke [The Problem of Socio-cultural Research in Modern Humanities] // Sovremennye problemy nauki i obrazovaniia [Modern Problems of Science and Education]. 2012. № 3. P. 323.

5. Bell, D. The Coming of Post-industrial Society. Moscow: Akademiia, 1999.

6. Cooley, Ch. Social Organization // Teksty po istorii sotsiologii XIX-XX vekov: Khrestomatiia. [Texts on the History of Sociology of the $19^{\text {th }}-20^{\text {th }}$ centuries: Reader] Moscow: Nauka, 1994.

7. Craig R.T. Communication Theory as a Field. International Communication Association, 1999.

8. Innis H. The Bias of Communication. Toronto: Toronto University Press, 1951.

9. Ilbeikina M.I. Vizual'no-antropologicheskaia spetsifika sovremennykh kul'turnykh praktik [Visual-anthropological Specificity of Modern Cultural Practices] // Sovremennye problemy nauki i obrazovaniia [Modern Problems of Science and Education]. 2013. № 3. P. 453.

10. Ilbeikina M.I. Nekotorye aspekty teorii sotsial'nykh tsennostei [ Some Aspects of the Theory of Social Values]// Sotsiodinamika [Sociodynamics]. 2014. № 12. P. 78-89. DOI: 10.7256/24097144.2014.12.13901. URL: http://e-notabene.ru/pr/article_13901.html

11. Ilbeikina M.I. Rol' vizual'noi antropologii v sotsial'nom konstruirovanii tsennostei [The Role of Visual Anthropology in the Social Construction of Values]. Dissertatsiia kandidata filosofskikh nauk po spetsial'nosti 09.00.11 sotsial'naia filosofiia [Thesis of Ph.D. with Major in Social Philosophy]. Krasnoyarsk, 2013.

12. Kagan M.S. Mir obshcheniia: Problema mezhsub'ektnykh otnoshenii [ The World of Communication: the Problem of Intersubjective Relationships] Moscow: Politizdat, 1988.

13. Kirko V.I., Nevzorov V.N. Innovatsionnye protsessy v Sibirskoi Arktike [Innovative Processes in Siberia Arctic] // Sotsiodinamika [Sociodynamics]. 2015. № 5. P. 70-82. DOI: 10.7256/24097144.2015.5.15325. URL: http://e-notabene.ru/pr/article_15325.html

14. Kistova A.V. Formirovaniie kommunikativnogo (interpretativnogo) etnograficheskogo metoda $v$ sovremennom sotsial'nom poznanii [Formation of the Communicative (Interpretive) Ethnographic Method in Modern Social Cognition]// NB: Problemy politiki i obshchestva [Challenges of Politics and Society]- 2014. № 11. P. 62-72. DOI: 10.7256/2306-0158.2014.11.1352. URL: http://e-notabene.ru/pr/ article_13527.html 
15. Kolesnik M.A. Sotsiologicheskie issledovaniia voobrazheniia v 30-e 80-e gg. XX veka [Sociological Research of Imagination in $30 \mathrm{~s} 80 \mathrm{~s}$ of the $20^{\text {th }}$ century]. // NB: Problemy politiki $i$ obshchestva [Challlenges of Politics and Society]- 2014. № 11. P. 45-61. DOI: 10.7256/23060158.2014.11.1351. URL: http://e-notabene.ru/pr/article_13517.html

16. Krasnykh V.V. (1998). Virtual'naia real'nost' ili real'naia virtual'nost?:chelovek, soznanie, kommunikatsiia [Virtual Reality or Real Virtuality? Human, Mind, Communication]. Dialog-Mgu.

17. Lasswell, H. Struktura i funktsii kommunikatsii v obshchestve [Structure and Communication Functions in Society]// Nazarov M.M. Massovaia kommunikatsiia v sovremennom mire: metodologiia analiza i praktika issledovanii [Nazarov M.M.: Mass Communication in the Modern World: Analysis Methodology and Practice of Research]. Moscow: EditorialURSS, 2002.

18. Libakova N.M., Koptseva N.P. Produktivnost' gendernogo podkhoda dlia gumanitarnykh issledovanii [Productivity of the Gender Approach to the Research in the Humanities]// Sovremennye problemy nauki i obrazovaniia [Modern Problems of Science and Education]. 2013. № 1. P. 400.

19. Luzan V.A. K probleme kontseptual'nykh osnovanii kul'turnoi politiki [To the Issue of the Conceptual Basis of Cultural Politics]// NB: Problemy politiki i obshchestva [Challenges of Politics and Society]. 2014. № 10. P. 135-158. DOI: 10.7256/2306-0158.2014.10.1342. URL: http://e-notabene. $\mathrm{ru} / \mathrm{pr} / \mathrm{article}$ _13420.html

20. Luhmann, N. Neveroiatnost' kommunikatsii [Incredibility of Communication]// Problemy teoreticheskoi sotsiologii [Problems of Theoretical Sociaology]. Issue 3 Saint-Petersburg: Publishing House of the Saint-Petersburg State University, 2000.

21. Luhmann, N.(1995). Chtotakoekommunikatsiia? [What is Communication?]. Sotsiologicheskii zhurnal [Sociological Journal], 3, 114-125.

22. Ma Liia. K voprosu ob osobenostyakh sotsial'nykh reklamnykh kommunikatsii v sovremennom kitaiskom obshchestve [To the Issue of Features of Social Advertising Communications in Modern Chinese Society]// Sotsiodinamika [Sociodynamics] 2015. № 2. P. 15-36. DOI: 10.7256/24097144.2015.2.14458. URL: http://e-notabene.ru/pr/article_14458.html

23. Ma Liia. Reklamnye kommunikatsii kak predmet sovremennogo sotsial'nogo poznaniia [Advertising Communication as a Subject of Contemporary Social Cognition]// Sovremennye problemy nauki i obrazovaniia [Modern Problems of Science and Education]. 2015. № 1. P. 1194.

24. Moles A. Social Dynamics of Culture. Moscow: Publishing House of Luchshie Komp'iuternye Igry [Best Computer Games], 2008.

25. Nazarchuk A.V. Uchenie Niklasa Lumana o kommunikatsii [Niklas Luhmann's Theory of Communication] // Moscow: Publishing House Ves' Mir- 2012.

26. Nikitina M.A., Pimenova N.N. Obraz zhizni Rossii v nachale XXI v. na materiale animatsii studii "Mel'nitsa" [Russian Lifestyle at the Beginning of the $21^{\text {st }}$ Century on the Material of the Animation Studio "Melnitsa"]// Elektronnyi nauchno-prakticheskii zhurnal "Kul'tura i obrazovanie" [Electronic Scientific Journal “Culture and Education”.] 2014. № 2 (6). P. 49.

27. Pocheptsov G.G. Teoriia kommunikatsii [Theory of Communication]. Moscow: Refl-buk, 2001.

28. Razumovskaya V.A. Semantika khudozhestvennogo obraza v originale i perevode: kot Begemot [Semantics of the Literary Image in the Original Text and in the Translation: cat Behemoth]// Problemy istorii, filologii, kul’tury [Problems of History, Philology and Culture]. 2012. № 3. P. 268. 
29. Reznikova K.V. Etnichnost' kak kategoriia sotsial'nogo poznaniia [Ethnicity as a Category of Social Cognition]// Sotsiodinamika [Sociodynamics] 2015. № 1. P. 101-111. DOI: 10.7256/24097144.2015.1.14228. URL: http://e-notabene.ru/pr/article_14228.html

30. Reznikova K.V., Koptseva N.P. Metodologicheskie vozmozhnosti antropologicheskoi shkoly "Kul'tura-i-Lichnost"” dlia sovremennykh rossiiskikh sotsial'no-kul'turnykh issledovanii [Methodological Possibilities of the Anthropological School "Culture-and-Personality" for Modern Russian Socio-cultural Studies] // Sovremennye problemy nauki i obrazovaniia [Modern Problems of Science and Education]. 2013. № 4. P. 388.

31. Rogers, E. M. Communication technology: The new media in society. New York: Free Press, 1986.

32. Schramm W. How communication works. In W. Schramm (Ed.), The process and effects of communication (pp. 3-26). Urbana, Illinois: University of Illinois Press, 1954.

33. Schramm, W. The science of human communication. New York: Basic Books, 1963.

34. Shannon C. E., \& Weaver, W. The mathematical theory of communication. Urbana, Illinois: University of Illinois Press, 1949.

35. Sharkov F.I. (2003). Osnovy teorii kommunikatsii [Basis of the Theory of Communication]. Moscow: Publishing House "Sotsial'nye otnosheniia".

36. Semenova A.A. Vizual'naia kul'tura modernizirovannogo sotsiuma [Visual Culture of the Modernized Society] // Vestnik Volgogradskogo gosudarstvennogo universiteta. Seriia 7. Filosofiia. Sotsiologiia i sotsial'nye tekhnologii [Bulletin of Volgograd State University. Series 7. Philosophy. Sociology and Social Technologies]. 2012. № 3. P. 145-149.

37. Seredkina N.N. Etnicheskaia kartina mira v kontekste sovremennykh sotsial'nykh issledovanii [Ethnic Picture of the World in the Context of Contemporary Social Research] // NB: Problemy politiki i obshchestva [Challenges of Politics and Society]. 2014. № 10. P. 26-59. DOI: 10.7256/23060158.2014.10.1344. URL: http://e-notabene.ru/pr/article_13441.html

38. Sertakova E.A. Sotsial'nyy konstruktivizm kak kontseptsiia konstruirovaniia etnosa [Social Constructivism as a Concept of Ethnos Construction] // Sovremennye problemy nauki i obrazovaniia [Modern Problems of Science and Education]. 2013. № 6. P. 999.

39. Sertakova E.A. Funktsionirovanie proizvedenii iskusstva v seti INTERNET [Functioning of Works of Art in the Internet] // Nauka i sovremennost' [Science and Modernity]. 2010. № 3-1. P. 64-68.

40. Sitnikova A.A.Kvoprosuometodologiiissledovaniikul'turykaksotsial'no-antropologicheskoi sistemy [On the Issue of Methodology of Studying Culture as a Socio-anthropological System] // Sotsiodinamika [Sociodynamics]. 2015. № 1. P. 75-100. DOI: 10.7256/2409-7144.2015.1.14237. URL: http://e-notabene.ru/pr/article_14237.html

41. Sitnikova A.A. Sovremennyye praktiki forsait-issledovaniia budushchego sotsial'noantropologicheskikh sistem, $v$ tom chisle etnokul'turnykh grupp severnykh regionov Rossiiskoi Federatsii [Modern Practices of Foresight Studies of the Future of Socio-anthropological Systems, Including Ethnic and Cultural Groups of the Northern Regions of the Russian Federation] // NB: Problemy politiki i obshchestva [Challenges of Politics and Society]. - 2014. № 9. P. 44-62. DOI: 10.7256/2306-0158.2014.9.13405. URL: http://e-notabene.ru/pr/article_13405.html

42. Sovremennaia zapadnaia sotsiologiia: slovar' [Modern Western Sociology: Dictionary] / Davydov Iu.N. et al. Moscow: Politizdat, 1990. 
43. Sokolov A.V. Obshchaia teoriia sotsial'noi kommunikatsii [General Theory of Social Communication]. Saint-Petersburg: Publishing House of V.A. Mikhailov, 2002.

44. Teoriia i praktika prikladnykh kul'turnykh issledovanii: regional'nyi proekt [Theory and Practice of Applied Cultural Research: Regional Project]. Saint-Petersburg: Eidos, 2013.

45. Toffler, A. The Third Wave. Moscow: AST, 2010.

46. Zamaraeva Iu.S. Osobennosti sotsiokul'turnykh transformatsii migratsionnykh protsessov $v$ $X X-X X I v v$. [Features of Social and Cultural Transformations of Migration Processes in the $20^{\text {th }}-21^{\text {st }}$ centuries]. Avtoreferat dissertatsii kandidata filosofskikh nauk [Dissertation of the Ph.D.] Novgorod, 2011.

\title{
Понятие «коммуникация» в современных научных исследованиях
}

\author{
Н.П. Копцева ${ }^{a}$, \\ Ма Лия' ${ }^{a}$ В.И. Кирко \\ ${ }^{a}$ Сибирский федеральный университет \\ Россия, 660041, Красноярск, пр. Свободныій, 79 \\ ${ }^{6}$ Красноярский государственный педагогический \\ университет им. В.П. Астафьева \\ Россия, 660060, Красноярск, ул. Ады Лебедевой, 89
}

Статья представляет собой обзор научных исследований феномена «коммуникация», в том числе историю становления теорий коммуникаций, моделей коммуникации, рассматриваютсямоделикоммуникацийразличных авторов. Хронологическийпериод анализа теорий и моделей коммуникации составляет около 100 лет: от 20-х г2. ХХ в. до настоящего времени. В статье анализируются современные дефицинии коммуникации отечественных и зарубежных авторов, раскрывается структура этих дефиниций, их основное содержание. Затем рассматриваются теории коммуникации - начиная от Гарри Найквиста и заканчивая Гарольдом Лассуэллом. В последнем разделе статьи в хронологическом порядке исследуются наиболее важные современные модели коммуникации таких авторов, как Шеннон и Уивер, Берло, Шрамм, Бернульд, Иннис, Крейг. В заключение делается вывод о современных тенденциях в исследованиях коммуникативных практик.

Ключевые слова: коммуникация, модели коммуникации, информация, социальныле коммуникации, кодирование и декодирование.

Исследование проведено в рамках выполнения гранта РГНФ 15-16-24007 на тему: «Комплексные исследования коренных малочисленных народов арктической зоны Восточной Сибири в области фундаментальной медицины, дистанциионной педагогики, сочиальнокультурной и экономической деятельности».

Научная специальность: 24.00.00 - культурология, 09.00.00 - философские науки. 